\title{
Analisis Kesalahan Siswa Kelas VIII SMP Katolik Sta. Rosa de Lima Tondano Dalam Menyelesaikan Soal Matematika Pada Materi Relasi dan Fungsi
}

\author{
Toar M. Kamagi ${ }^{*}$, Patricia V.J. Runtu1
}

1Pendidikan Matematika, Fakultas Matematika dan Ilmu Pengetahuan Alam, Universitas Negeri Manado

*e-mail: toarmk@gmail.com

\begin{abstract}
ABSTRAK
Tujuan dari penelitian ini yaitu untuk mengetahui kesalahan dan faktor penyebabnya dalam menyelesaikan soal relasi dan fungsi. Jenis penelitian ini menggunakan penelitian deskriptif kualitatif. Teknik pengumpulan data yang dilakukan yaitu, tes tertulis dalam bentuk 6 item soal uraian dan wawancara. Subjek penelitian ini yaitu siswa kelas VIII SMP Katolik Sta. Rosa de Lima Tondano TA 2020/2021 yang dipilih berdasarkan pertimbangan. Analisis data yang digunakan yaitu tahapan Mereduksi data, menyajikan data, kemudian menarik kesimpulan. Hasil penelitian diperoleh dari kelima jenis kesalahan siswa menyelesaikan soal pada materi relasi dan fungsi, kesalahan yang paling sering terjadi yaitu kesalahan prinsip dengan persentase sebesar 38,98\%, kemudian kesalahan prosedur dengan persentase sebesar 30,51\%, kemudian kesalahan fakta, kesalahan konsep, dan kesalahan cara penyimpulan sebesar $10,17 \%$. Faktor penyebabnya, yaitu: 1) tidak tahu menyatakan suatu relasi kedalam himpunan pasangan berurutan. 2) mengerjakan soal secara terburu-buru. 3) tidak memahami konsep domain, kodomain, dan range. 4) tidak tahu menentukan hasil pemetaan dari domain ke kodomain. 5) tidak tahu prosedur operasi perhitungan bilangan. 6) tidak tahu prosedur mencari nilai fungsi. 7) tidak teliti dalam mengerjakan soal. 8) belum memahami konsep dari fungsi.
\end{abstract}

Kata kunci: Analisis, Kesalahan, Relasi dan Fungsi

\begin{abstract}
The aims of this research is to find out the errors and factors that cause errors in solving relationand function problems. This type of research uses descriptive qualitative research. Data collection techniques used, namely through written tests in the form of a description of 6 items, interviews. The subjects of this study were students of grade VIII Catholic Junior High School Sta. Rosa de Lima Tondano TA 2020/2021 selected based on consideration. Data analysis used is the stage of reducing data, presenting data, then drawing conclusions.. The results of the research were obtained from the five types of errors students solve problems in relations and functions, the most common errors are principle errors with a percentage of $38.98 \%$, then procedure errors with a percentage of $30.51 \%$, then factual errors, concept errors, and errors in how to collect by $10.17 \%$. The causative factor, namely: 1) do not know to declare a relation into a set of consecutive pairs. 2) work on the problem in a hurry. 3) do not understand the concept of domain, codomain, and range. 4) do not know determine the results of mapping from domain to codomain. 5) do not know the procedure of number calculation operation. 6) do not know the procedure of finding the value of the function. 7) not thorough in working on the problem. 8) do not yet understand the concept of the function.
\end{abstract}

Keywords: Analysis, Errors, Relation and Function

\section{PENDAHULUAN}

Menurut Djamarah (dalam Rofi'ah dkk., 2019) Salah satu kegiatan secara sadar untuk meningkatkan kapasitas dalam suatu sistem pendidikan yang utuh yaitu dengan pendidikan. Mutu pendidikan dapat ditingkatkan dengan membekali siswa dengan berbagai mata pelajaran, salah satunya matematika.

Matematika adalah ilmu dalam melatih cara berpikir yang rasional serta logis untuk memperoleh konsep (Isrok'atun \& Rosmala, 2018). Matematika merupakan ilmu dimana objek yang dikaji yaitu fakta, prosedur, konsep serta prinsip yang sifatnya abstrak. Konsep dalam matematika saling berketerkaitan, sehingga siswa perlu memahami konsep yang sebelumnya untuk memahami konsep selanjutnya. Dalam proses pemecahan matematika, siswa diharuskan mengaitkan semua konsep yang telah dipelajari (Rahmawati \& Permata, 2018). Jika siswa 
kurang memahami konsep materi tertentu, maka berimbas pada materi berikutnya, yang berakibat siswa kesulitan untuk memahami materi dan pada akhirnya melakukan kesalahan dalam menyelesaikan soal (Nurianti dkk., 2015).

Salah satu materi yang akan dipelajari oleh siswa kelas VIII Sekolah Menengah Pertama (SMP) yaitu relasi dan fungsi. Menurut Callaghan dalam Nalole (dalam Kamariah \& Marlissa, 2016) fungsi merupakan salah satu konsep yang sangat penting. Fungsi sangat penting dalam kehidupan setiap hari dan juga dalam mempelajari matematika di sekolah. Memahami konsep untuk konsep matematika lainya merupakan peran dari fungsi. Materi fungsi pada tingkat SMP merupakan konsep awal yang akan digunakan ke jenjang lebih tinggi (Kamariah \& Marlissa, 2016). Dalam materi relasi dan fungsi, banyak konsep baru yang wajib dipahami anak didik supaya Kompetensi Dasar yang diperlukan dapat tercapai. Konsep relasi dan fungsi juga pertama kali diperkenalkan pada anak didik pada tingkat SMP. Oleh karenanya, tidak sedikit anak didik cenderung sulit memahami materi. Dalam mengerjakan soal pun, masih sering dijumpai kesalahan yang dilakukan anak didik (Raharjo \& Christanti, 2020).

Kesimpulan dari hasil penelitian oleh Pacarita \& Dewi (2019) di kelas VIII SMP Negeri 1 Sepang mengatakan bahwa: kesalahan fakta yang terjadi yaitu siswa salah dalam menuliskan rumus fungsi dan nilai fungsi $f$ dari soal, kemudian kesalahan konsep yang terjadi yaitu salah dalam memahami konsep relasi dan fungsi. Siswa tidak mampu membedakan antara relasi dan fungsi. Salah memahami konsep pasangan terurut. Salah menentukan elemen pada pasangan berurutan pada sumbu- $X$ maupun sumbu- $Y$. Selanjutnya kesalahan operasi yang terjadi yaitu, salah melakukan operasi bilangan dan operasi bentuk aljabar, dan kesalahan prinsip yang terjadi salah menerapkan prinsip untuk menyatakan relasi maupun fungsi dengan diagram panah, HPB, serta grafik Kartesius (Pacarita \& Dewi, 2019).

Berdasarkan pengalaman penulis selama melaksanakan Program Pengalaman Lapangan Gelombang 1 di SMP Katolik Sta. Rosa de Lima Tondano, siswa sering mengalami kebingungan tentang konsep fungsi. Dibandingkan dengan materi relasi, siswa lebih mudah memahami materi relasi daripada materi fungsi. Dalam mempelajari materi fungsi, siswa kadang kesulitan untuk bedakan mana yang fungsi dan mana yang bukan fungsi yang dinyatakan dalam diagram panah disertai alasannya. Siswa juga mengalamai kesulitan dalam menghitung nilai fungsi. Sehingga dampaknya banyak siswa yang tidak memahami penyelesaian dari soal relasi dan fungsi. Akibatnya masih terdapat kesalahan dalam hasil pekerjaan mereka.

Untuk memperbaiki serta meminimalisir kesalahan yang dilakukan siswa, diperlukannya menganalisis kesalahan siswa yang terjadi pada penyelesaian soal, terutama pada materi relasi dan fungsi. Bukan cuma mengetahui kesalahan yang terjadi tetapi diperlukan juga mengetahui apa yang menyebabkan kesalahan dalam menyelesaikan soal itu terjadi.

Dari uraian sebelumnya, penulis merasa penting untuk menganalisis kesalahan yang terjadi dalam menyelesaikan soal relasi dan fungsi serta faktor penyebabnya untuk memperbaiki dan meminimalisir kesalahan dalam menyelesaikan soal pada materi relasi dan fungsi.

\section{METODE}

Penelitian ini menggunakan penelitian deskriptif dengan pendekatan kualitatif. Lokasi penelitian di SMP Katolik Sta. Rosa de Lima Tondano dan akan dilaksanakan pada Sem. Ganjil TA 2020/2021 Penelitian ini diikuti 11 siswa kelas VIII SMP Katolik Sta. Rosa de Lima Tondano. Pada penelitian ini, peneliti akan menggunakan purposive sampling. Dimana subjek dipilih atas beberapa pertimbangan, variasi bentuk kesalahan pada tes tertulis, keterbukaan dan kelancaran dalam berkomunikasi lisan, dan bertempat tinggal disekitar sekolah. Peneliti sendiri sebagai instrumen penelitian ini. Instrumen dari penelitian kualitatif yaitu peneliti yang melaksanakan penelitian itu sendiri (Sugiyono, 2016).

Terdapat dua teknik pengumpulan data yang dilakukan yaitu, tes tertulis dalam bentuk 6 item soal uraian yang sudah divalidasi oleh dosen pembimbing yang fungsi untuk melihat kesalahan siswa dalam menyelesaikan soal dan wawancara tidak berstruktur, dimana wawancara dilaksanakan tanpa menggunakan panduan wawancara (Sugiyono, 2016).

Prosedur pelaksanaan penelitian, pertama pemberian tes tertulis, kemudian merekapitulasi hasil ter tertulis siswa, selanjutnya mengidentifikasi kesalahan siswa dan menganalisis dari hasil tadi, kemudian memilih siswa yang akan diwawancarai, selanjutnya melaksanakan wawancara, dan 
membuat kesimpulan dari hasil analisis tes dan wawancara. Analisis data yang digunakan yaitu tahapan analisis data Miles dan Huberman yaitu mereduksi, menyajikan, kemudian menyimpulkan (Sugiyono, 2016).

\section{HASIL DAN PEMBAHASAN}

Penelitian ini dilaksanakan pada bulan November 2020 dan diikuti oleh 11 siswa kelas VIII SMP Katolik Sta. Rosa de Lima Tondano. Adapun hasil analisis kesalahan pada tes tertulis yang sajikan dalam bentuk Tabel 1 berikut ini.

Tabel 1. Hasil Analisis Kesalahan Pada Tes Tertulis

\begin{tabular}{ccccccc}
\hline Subjek & \multicolumn{7}{c}{ Jenis Kesalahan Pada Item Soal Nomor } \\
\cline { 2 - 7 } (Siswa) & $\mathbf{1}$ & $\mathbf{2}$ & $\mathbf{3}$ & $\mathbf{4}$ & $\mathbf{5}$ & $\mathbf{6}$ \\
\hline $\mathrm{R}-1$ & $b$ & $y$ & $x$ & $c$ & $d$ & $c, d, y$ \\
\hline $\mathrm{R}-2$ & $y$ & $a, c, e$ & $x$ & $x$ & $x$ & $x$ \\
\hline $\mathrm{R}-3$ & $c, y$ & $c, y$ & $x$ & $x$ & $d$ & $x$ \\
\hline $\mathrm{R}-4$ & $c, b$ & $a, c, y$ & $x$ & $d, c$ & $d$ & $c, d, y$ \\
\hline $\mathrm{R}-5$ & $c$ & $c, y$ & $x$ & $x$ & $d, y$ & $c, d, y$ \\
\hline $\mathrm{R}-6$ & $c$ & $c, e$ & $a, e$ & $d, c$ & $d$ & $d, c, y$ \\
\hline $\mathrm{R}-7$ & $c, b$ & $a, e$ & $x$ & $d, c, y$ & $y$ & $x$ \\
\hline $\mathrm{R}-8$ & $d, b$ & $a, c, y$ & $x$ & $d, y$ & $x$ & $x$ \\
\hline $\mathrm{R}-9$ & $b, c$ & $a, c, e$ & $x$ & $d, y$ & $x$ & $x$ \\
\hline $\mathrm{R}-10$ & $b, c$ & $c, e$ & $x$ & $d, y$ & $y$ & $x$ \\
\hline $\mathrm{R}-11$ & $d$ & $y$ & $x$ & $y$ & $d$ & $x$ \\
\hline & & & & &
\end{tabular}

Keterangan :

$a$ : Kesalahan Fakta

$b$ : Kesalahan Konsep

$c$ : Kesalahan Prinsip

$d$ : Kesalahan Prosedur

$e$ : Kesalahan Cara Penyimpulan

$x$ : Tidak dijawab

$y$ : Tidak melanjutkan jawaban

${ }^{*} x$ dan $y$ tidak termasuk dalam kesalahan

Berdasarkan hasil analisis pada tes tertulis pada Tabel 1, banyaknya jenis kesalahan yang dilakukan siswa pada penyelesaian soal relasi dan fungsi pada setiap item soal dan persentase setiap jenis kesalahan adalah sebagai berikut.

Tabel 2. Banyaknya Jenis Kesalahan Pada Penyelesaian Soal Relasi dan Fungsi Pada Setiap Item Soal dan Persentase Dari Setiap Jenis Kesalahan

\begin{tabular}{|c|c|c|c|c|c|c|c|c|}
\hline \multirow[t]{2}{*}{ Jenis Kesalahan } & \multicolumn{6}{|c|}{$\begin{array}{c}\text { Banyaknya Kesalahan Yang Dilakukan } \\
\text { Siswa Pada Item Nomor }\end{array}$} & \multirow{2}{*}{$\begin{array}{l}\text { Jumlah Kesalahan Per } \\
\text { Setiap Jenis Kesalahan }\end{array}$} & \multirow[t]{2}{*}{ Persentase } \\
\hline & 1 & 2 & 3 & 4 & 5 & 6 & & \\
\hline Kesalahan Fakta & 0 & 5 & 1 & 0 & 0 & 0 & 6 & $10,17 \%$ \\
\hline Kesalahan Konsep & 6 & 0 & 0 & 0 & 0 & 0 & 6 & $10,17 \%$ \\
\hline Kesalahan Prinsip & 7 & 8 & 0 & 4 & 0 & 4 & 23 & $38.98 \%$ \\
\hline Kesalahan Prosedur & 2 & 0 & 0 & 6 & 6 & 4 & 18 & $30,51 \%$ \\
\hline $\begin{array}{l}\text { Kesalahan Cara } \\
\text { Penyimpulan }\end{array}$ & 0 & 5 & 1 & 0 & 0 & 0 & 6 & $10,17 \%$ \\
\hline $\begin{array}{l}\text { Jumlah Kesalahan } \\
\text { Per Item }\end{array}$ & 15 & 18 & 2 & 10 & 6 & 8 & 59 & \\
\hline
\end{tabular}


Berdasarkan hasil analisa kesalahan pada tes tertulis dan hasil wawancara diketahui kesalahan yang dilakukan siswa dalam menyelesaikan soal pada relasi dan fungsi, yaitu:

1. Kesalahan Konsep

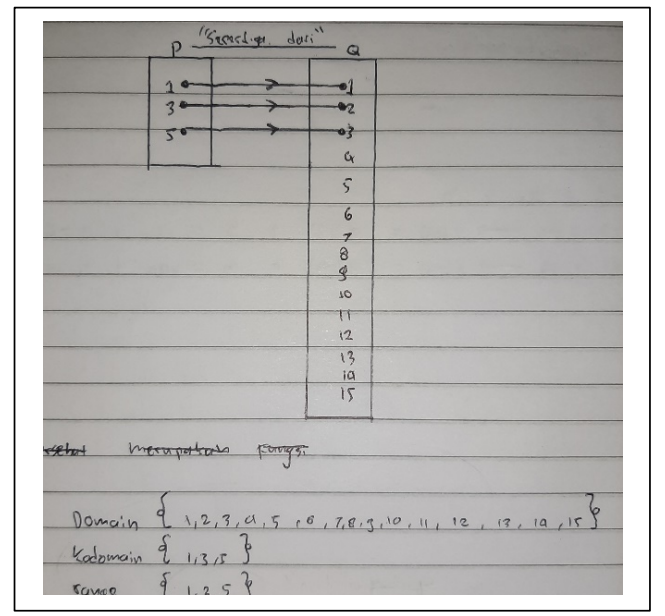

Gambar 1. Contoh Kesalahan Konsep Oleh Siswa R-7 Pada Item No.1

Pada Gambar 1 siswa R-7 sudah benar dalam menentukan anggota dari himpunan $P$ dan himpunan $Q$ tetapi siswa kesalahan konsep dalam menentukan domain, kodomain, dan range. Persentase jenis kesalahan ini yaitu, 10,17\%. Kesalahan konsep dalam menyelesaikan soal relasi dan fungsi, yaitu salah dalam memahami konsep dari kodomain, domain, serta range, yang disebabkan karena siswa tak ingat apa itu kodomain, domain, serta range yang telah dipelajari.

2. Kesalahan Fakta

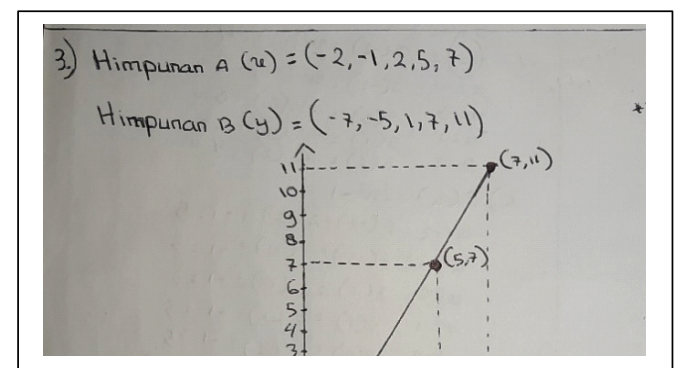

Gambar 2. Contoh Kesalahan Fakta Oleh Siswa R-1 Pada Item No.3

Pada Gambar 2 siswa R-6 sudah benar dalam menentukan anggota dari himpunan $A$ dan himpunan $B$, tapi siswa siswa R-6 melakukan kesalahan fakta dalam yaitu salah menuliskan notasi himpunan dari himpunan " \{\} ". Persentase jenis kesalahan ini yaitu, 10,17\%. Kesalahan fakta dalam menyelesaikan soal relasi dan fungsi, yaitu kesalahan tidak menuliskan notasi dari himpunan " \{\} ". Hal ini disebabkan karena berbagai macam alasan. Pertama, karena tidak tahu penyajian dari relasi dan fungsi dengan menggunakan himpunan pasangan berurutan. Kedua, sudah tahu notasi atau simbol dari himpunan, tetapi lupa menulisnya karena mengerjakan soal secara terburu-buru.

3. Kesalahan Prinsip

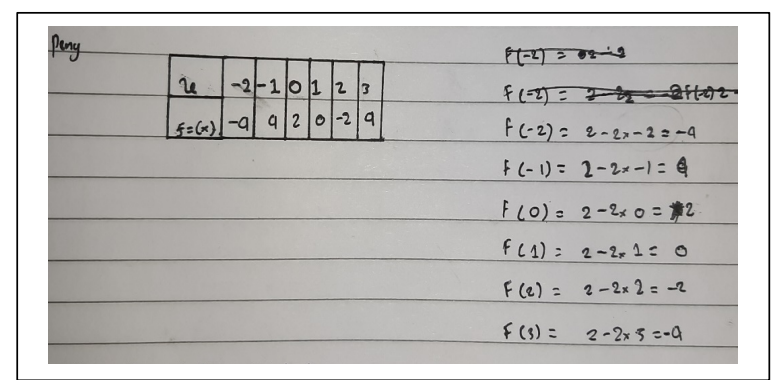

Gambar 3. Contoh Kesalahan Prinsip Oleh Siswa R-7 Pada Item No.4 
Pada Gambar 3 siswa R-7 melakukan kesalahan prinsip, yaitu salah menyajikan fungsi $f(x)=2-$ $2 x$ dengan domainnya $\{2,-1,0,1,2,3\}$ ke dalam tabel. Persentase jenis kesalahan ini yaitu, 38,98\%. Kesalahan prinsip dalam menyelesaikan soal relasi dan fungsi, yaitu: 1) salah dalam menyatakan suatu relasi kedalam himpunan pasangan berurutan, penyebabnya yaitu siswa tak tahu apa itu penyajian dari himpunan pasangan berurutan. 2) salah dalam menyatakan suatu relasi ke dalam diagram panah, hal ini disebabkan karena siswa salah menentukan hasil pemetaan dari domain ke kodomain. 3) salah dalam menyatakan suatu fungsi ke dalam bidang Kartesius dan diagram panah, hal ini disebabkan karena salah dalam prosedur perhitungan pada nilai fungsi.

4. Kesalahan Prosedur

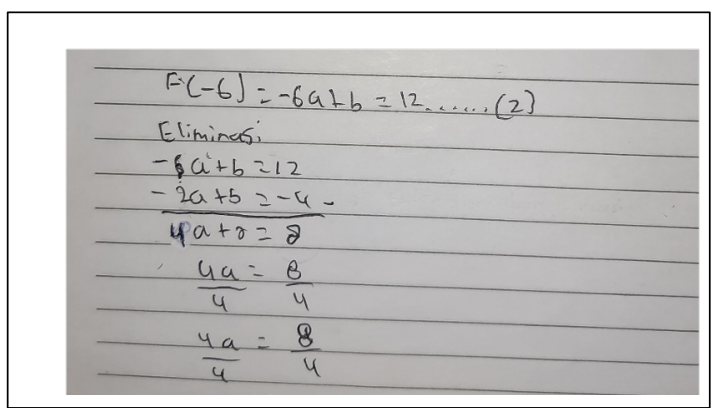

Gambar 4. Contoh Kesalahan Prosedur Oleh Siswa R-1 Pada Item No.5

Pada Gambar 4 siswa R-1 melakukan kesalahan prosedur perhitungan pada bagian mengeliminasi variabel $b$. Siswa R-1 salah menghitung $12-(-4)$ sama dengan 8 . Karena sudah salah dalam prosedur perhitungan dalam mengeliminasi, maka nilai a yang diperoleh salah. Berakibat penyelesaian selanjutnya juga sudah salah. Persentase jenis kesalahan ini yaitu, 30,51\%. Kesalahan prosedur dalam menyelesaikan soal relasi dan fungsi, yaitu: 1) salah dalam melakukan prosedur operasi perhitungan, hal ini disebabkan siswa tidak tahu cara melakukan prosedur operasi perhitungan yang benar dan juga tidak teliti dalam melakukan prosedur perhitungan. 2) siswa salah dalam menentukan nilai fungsi, hal ini disebab karena siswa tidak tahu prosedur mencari nilai fungsi yang benar.

5. Kesalahan Cara Penyimpulan

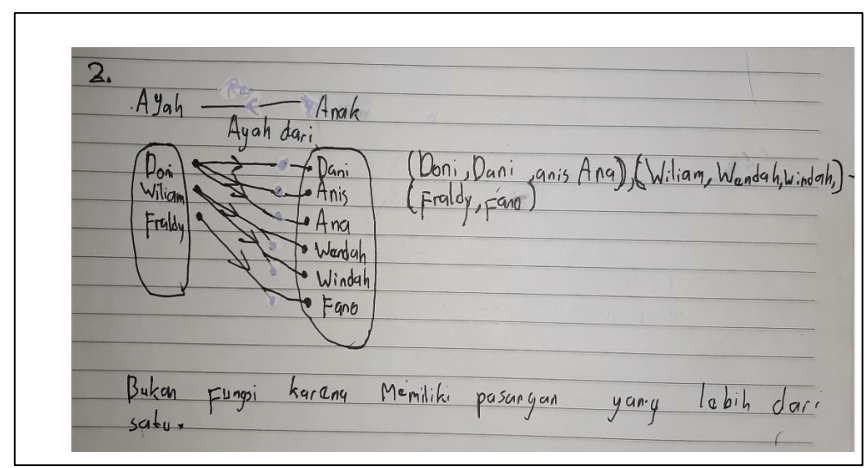

Gambar 5. Contoh Kesalahan Cara Penyimpulan Oleh Siswa R-2 Pada Item No.2

Pada Gambar 5 siswa R-2 melakukan kesalahan cara penyimpulan, dimana alasan yang diberikan yaitu, relasi "Ayah dari" apakah fungsi atau bukan fungsi masih belum tepat. Persentase jenis kesalahan ini yaitu, $10,17 \%$. Kesalahan cara penyimpulan dalam menyelesaikan soal relasi dan fungsi, yaitu salah memberikan alasan mengapa relasi antara dua himpunan yang diberikan disoal merupakan sebuah fungsi atau bukan fungsi, penyebabnya karena siswa belum paham pengertian dari fungsi. 


\section{KESIMPULAN}

Berdasarkan hasil penelitian yang telah disajikan dan telah dilakukan pada siswa kelas VIII di SMP Katolik Sta. Rosa de Lima Tondano maka dapat disimpulkan :

1. Dari kelima jenis kesalahan siswa menyelesaikan soal relasi dan fungsi, kesalahan yang paling sering terjadi yaitu kesalahan prinsip yang persentasenya 38,98\%, kemudian kesalahan prosedur dengan persentase sebesar 30,51\%, kemudian kesalahan fakta, kesalahan konsep, dan kesalahan cara penyimpulan sebesar 10,17\%. Kesalahan yang dilakukan siswa kelas VIII di SMP Katolik Sta. Rosa de Lima Tondano dalam menyelesaikan soal-soal relasi dan fungsi, yaitu: 1) kesalahan fakta, dimana siswa tak menuliskan notasi simbol himpunan. 2) kesalahan dalam memahami konsep domain, kodomain, dan range. 3) kesalahan prinsip, dimana salah menyatakan suatu relasi ke dalam HPB dan diagram panah. 4) kesalahan prinsip, dimana salah menyatakan fungsi kedalam diagram panah. 5) kesalahan prosedur, dimana salah dalam prosedur operasi perhitungan. 6) kesalahan prosedur, dimana salah dalam menentukan nilai fungsi. 7) kesalahan cara penyimpulan, dimana salah dalam memberikan alasan mengapa suatu relasi antara dua himpunan yang diberikan merupakan fungsi atau bukan fungsi.

2. Faktor yang menyebabkan siswa kelas VIII SMP Katolik Sta. Rosa de Lima Tondano melakukan kesalahan dalam menyelesaikan soal relasi dan fungsi, yaitu: 1) tidak tahu menyatakan suatu relasi kedalam HPB. 2) mengerjakan soal secara terburu-buru. 3) tidak memahami konsep domain, kodomain, dan range. 4) tidak tahu menentukan hasil pemetaan dari domain ke kodomain. 5) tidak tahu prosedur operasi perhitungan bilangan yang benar. 6) tidak tahu prosedur mencari nilai fungsi yang benar. 7) tidak teliti dalam mengerjakan soal. 8) belum memahami konsep dari fungsi.

\section{DAFTAR PUSTAKA}

Isrok'atun, \& Rosmala, A. (2018). Model-Model Pembelajaran Matematika (B. S. Fatmawati (ed.)). Jakarta: PT Bumi Aksara.

Kamariah, \& Marlissa, I. (2016). Analisis Kesalahan Menyelesaikan Soal Relasi dan Fungsi Pada Siswa Kelas VIII SMP Negeri Buti Merauke. Magistra, 3(1), 30-42. doi: 10.35724/magistra.v3i1.387

Nurianti, E., Halini, \& Romal. (2015). Analisis Kesalahan Siswa Dalam Menyelesaikan Soal Matematika Materi Pecahan Bentuk Aljabar Di Kelas VIII SMP. Jurnal Pendidikan Dan Pembelajaran Khatulistiwa, 4(9), 1-11. Diambil dari https://jurnal.untan.ac.id/index.php/jpdpb/article/view/11187

Pacarita, \& Dewi, K. (2019). Identifikasi Kesalahan Siswa dalamMenyelesaikan Soal Relasi dan Fungsi di Kelas VIII SMP Negeri 1 Sepang. Jurnal Pendidikan., 20(2), 67-78. Diambil dari https://e-journal.upr.ac.id/index.php/JPN/article/view/885

Raharjo, A. M., \& Christanti, A. D. I. (2020). Analisis Kesalahan Siswa Kelas VIII SMP Kanisius Gayam Dalam Menyelesaikan Soal Relasi dan Fungsi. Journal Program Studi Pendidikan Matematika, Fakultas Keguruan Dan Ilmu Pendidikan, Universitas Sanata Dharma, 1(1), 281-292. Diambil

dari https://proceeding.unikal.ac.id/index.php/sandika/article/view/421

Rahmawati, D., \& Permata, L. D. (2018). Analisis Kesalahan Siswa Dalam Menyelesaikan Soal Cerita Program Linear Dengan Prosedur Newman. Jurnal Elektronik Pembelajaran Matematika, 5(2), 173-185. Diambil dari https://jurnal.uns.ac.id/jpm/article/view/26050

Rofi'ah, N., Ansori, H., \& Mawaddah, S. (2019). Analisis Kesalahan Siswa Dalam Menyelesaikan Soal Cerita Matematika Berdasarkan Langkah Penyelesaian Polya. EDU-MAT: Jurnal Pendidikan Matematika, 7(2), 120. doi: 10.20527/edumat.v7i2.7379

Sugiyono. (2016). Metodologi Penelitian Pendidikan (Pendekatan Kuantitatif, Kualitatif, dan $R \& D)$. Bandung: Alfabeta. 